Abstracta Iranica Abstracta Iranica

Revue bibliographique pour le domaine irano-aryen

Volume 26 | 2005

Comptes rendus des publications de 2003

\title{
La memoria romana dei santi martiri persiani Mario, Marta, Audiface e Abaco. Rome, 2003, 32 p.
}

Christelle Jullien

\section{Q OpenEdition \\ 12 Journals}

Édition électronique

URL : http://journals.openedition.org/abstractairanica/2476

ISSN : 1961-960X

\section{Éditeur :}

CNRS (UMR 7528 Mondes iraniens et indiens), Éditions de l'IFRI

\section{Édition imprimée}

Date de publication : 15 mai 2005

ISSN : 0240-8910

\section{Référence électronique}

Christelle Jullien, «La memoria romana dei santi martiri persiani Mario, Marta, Audiface e Abaco. Rome, 2003, 32 p. », Abstracta Iranica [En ligne], Volume 26 | 2005, document 299, mis en ligne le 07 décembre 2005, consulté le 25 septembre 2020. URL : http://journals.openedition.org/ abstractairanica/2476

Ce document a été généré automatiquement le 25 septembre 2020.

Tous droits réservés 


\title{
La memoria romana dei santi martiri persiani Mario, Marta, Audiface e Abaco. Rome, 2003, 32 p.
}

\author{
Christelle Jullien
}

\begin{abstract}
A.-M. Piemontese analyse dans ce petit livret l'histoire d'une famille chrétienne venue de Perse en pèlerinage à Rome vénérer les reliques des premiers martyrs et honorer les apôtres Pierre et Paul. Le père, la mère et leurs deux fils périssent lors de la persécution anti-chrétienne déclenchée par Claude II le Goth dans la seconde moitié du $3^{\mathrm{e}} \mathrm{s}$. Cette Passion aurait été rédigée au $5^{\mathrm{e}}-6^{\mathrm{e}} \mathrm{s}$. L'A. examine l'authenticité des documents latins et a recours aux données archéologiques romaines. Il envisage prochainement d'écrire une monographie sur l'ensemble des saints persans paléochrétiens vénérés à Rome.
\end{abstract}

\section{INDEX}

Thèmes : 6.3. Autres religions

\section{AUTEURS}

CHRISTELLE JULLIEN

CNRS - Paris 